\title{
Polychaetes of the genus Ampharete (Polychaeta: Ampharetidae) collected in Icelandic waters during the BIOICE project
}

\author{
Julio Parapar · Gudmundur V. Helgason • \\ Igor Jirkov $\cdot$ Juan Moreira
}

Received: 15 June 2010 / Revised: 14 August 2011 / Accepted: 2 September 2011 / Published online: 22 September 2011

(C) Springer-Verlag and AWI 2011

\begin{abstract}
Based on material collected during the BIOICE project off Iceland, the taxonomy and distribution of eight species of polychaetous annelids belonging to the genus Ampharete (Polychaeta: Ampharetidae) are reviewed. Five of these species were previously reported in the area: Ampharete acutifrons, Ampharete borealis, Ampharete finmarchica, Ampharete octocirrata and Ampharete petersenae; two are new to Icelandic waters: Ampharete baltica and Ampharete lindstroemi; and one is new to science: Ampharete villenai sp. nov. A. petersenae was found for the first time after the original description and is redescribed. A. villenai sp. nov. is primarily characterized by
\end{abstract}

Communicated by Peter Funch.

J. Parapar ( $\square)$

Departamento de Bioloxía Animal, Bioloxía Vexetal e Ecoloxía, Facultade de Ciencias, Universidade da Coruña,

Alejandro da Sota 1, 15008 A Coruña, Spain

e-mail: jparapar@udc.es

\section{G. V. Helgason}

Institute of Biology, University of Iceland,

Sturlugata 7, 101 Reykjavík, Iceland

I. Jirkov

Department of Hydrobiology, Biological Faculty,

Moscow State University, Moscow, Russia

\section{J. Moreira}

Estación de Bioloxía Mariña da Graña,

Universidade de Santiago de Compostela,

Rúa da Ribeira 1, A Graña, 15590 Ferrol, Spain

\section{J. Moreira}

Departamento de Biología (Zoología), Facultad de Ciencias, Universidad Autónoma de Madrid, Cantoblanco,

28049 Madrid, Spain the size, shape and disposition of the paleae, a special kind of chaetae located on the first body chaetiger. Several body characters of high taxonomic relevance in Ampharetidae are reviewed under the SEM. The distribution of each species off the coast of Iceland and a key to all species recorded in European Boreo-Arctic waters is provided.

Keywords Polychaeta Ampharetidae $\cdot$ Ampharete . Iceland $\cdot$ New species $\cdot$ BIOICE project

\section{Introduction}

The genus Ampharete Malmgren, 1866, with about 30 described species (Jirkov 1994) is the most speciose genus in the family Ampharetidae Malmgren, 1866. This number would exceed 40 species if Asabellides and Sabellides are considered synonymous. It is composed of surface depositfeeding polychaetes that live on soft bottoms from the intertidal down to abyssal depths (Salazar-Vallejo 1996). Since its creation by Malmgren (1866), the genus has been well characterized, not undergoing significant changes in its diagnosis after the classical reviews by Hessle (1917), Day (1964) and Holthe (1986a). Thus, the main diagnostic characters used to be included are the presence of papillose buccal tentacles, four pairs of branchiae, presence of paleae (a special kind of forward-pointing chaetae, located on the third body segment), 14 thoracic chaetigers with notosetae (15 when considering paleae) and 12 with neurosetae and 12-26 abdominal segments (Reuscher et al. 2009). Nevertheless, Jirkov (1994, 2001, 2009) questions the taxonomic validity of the presence/absence of paleae. He showed that within some Ampharetinae genera traditionally considered as provided with paleae, the form and number of this kind of chaetae can vary significantly, suggesting that their 
presence/absence should not be used for generic definition. Thus, in Ampharete, a variation from huge well-developed paleae (A. longipaleolata Ushakov, 1950) to completely absent (A. sibirica (Wiren, 1883) and A. petersenae Jirkov, 1997 ) is noted. Also, a species devoid of paleae was also recently described within the genus Anobothrus Levinsen, 1884 , i.e. Anobothrus apaleatus Reuscher, Fiege \& Wehe, 2009. Moreover, Jirkov $(1994,2009)$ reported that the facultative absence of paleae in some specimens (ca. 5\%) of a population of Ampharete saphronovae Jirkov 1994, a species described with paleal chaetae of almost the same size as the thoracic notochaetae, concluding that even for species diagnosis this character should be used with care. According to this, we consider the genus Asabellides Annenkova, 1929 as a junior synonym of Ampharete because both genera were only distinguished by the absence of paleae in the former. Furthermore, we also follow Jirkov $(2001,2009)$ in considering the presence of 13 thoracic chaetigers (genus Sabellides Milne-Edwards, 1838 in Malmgren 1866) instead of 14, as character states that do not justify the discrimination of genera. Consequently, the genus Ampharete sensu Jirkov (1994, 1997, 2001, 2009) would include ampharetids with or without paleae, with four pairs of smooth branchiae, papillose buccal tentacles, 13-14 thoracic chaetigers (excluding paleae) provided with notochetae and 11-12 thoracic uncinigers.

Since Holthe (1986a) reported 7 species of Ampharete in North Atlantic waters, only Jirkov (2001), within a larger study on Arctic Polychaeta, reviewed the presence of this genus in northern European waters. The scattered information on this genus in Icelandic waters was first compiled by Wesenberg-Lund (1951), who mentions Ampharete acutifrons (Grube, 1860), Ampharete goesi Malmgren, 1866 (as A. goësi), Ampharete borealis (Sars, 1856) (as Sabellides) and Ampharete octocirrata (Sars, 1835) (as Sabella). Later, Gardarsson (1973) reports the presence of Ampharete finmarchica (Sars, 1866) and recently Jirkov (1997) described a new species, Ampharete petersenae Jirkov, 1997, from the east coast.

The BIOICE (Benthic Invertebrates of Icelandic Waters) expeditions were part of an international collaborative programme that started in 1992 to conduct a thorough survey of the marine benthic fauna living in the 200 mile exclusive economic zone (EEZ) of Iceland. Eight species belonging to the genus Ampharete sensu Jirkov (1994) were identified from material collected in those expeditions. Five species have previously been reported in Icelandic waters, namely Ampharete acutifrons, Ampharete borealis, Ampharete finmarchica, Ampharete octocirrata and Ampharete petersenae; the latter is reported for the first time after the original description and is redescribed. Ampharete baltica Eliason, 1955 and Ampharete lindstroemi Malmgren in
Hessle, 1917 are new for the studied area. Ampharete villenai sp. nov. is new to science and described herein. Ampharete goesi Malmgren, 1866, a mostly Arctic species (type locality Spitsbergen) but also reported from the Okhotsk Sea and Japan Sea (NW Pacific), was the only previously reported species that was not found in this study. Furthermore, two other species known from North Atlantic and the Arctic, respectively, were not present in the BIOICE samples, i.e. Ampharete falcata Eliason, 1955 (low-boreal species; type locality Swedish west coast) and Ampharete vega (Wirén, 1883) (shallow-water Arctic euryhaline species, type locality Bering Sea).

The use of the scanning electronic microscope (SEM) has been proved a useful tool in the study of external structures of polychaetes in general and those of the clade Terebellomorpha in particular (Hutchings and Peart 2000; Jouin-Toulmond and Hourdez 2006; Parapar and Moreira 2008a, b). In this work, the SEM has been used to elucidate some anatomical characteristics, which are difficult to observe under the compound microscope, such as the presence and distribution of body ciliature and the shape of paleae, notochaetae and uncini.

The BIOICE sampling area covers a depth range from 20 to $3,500 \mathrm{~m}$ on both sides of the Greenland-Iceland-Faeroe Ridge (GIF Ridge), which is generally less than $500 \mathrm{~m}$ deep and marks the boundary between the relatively warm North Atlantic Ocean and the much colder Nordic seas of the Arctic Ocean. Other papers dealing with BIOICE polychaetes were those of Petersen (2000) on Fauveliopsidae, Kirkegaard (2001) on Glyceridae and Goniadidae, Sanfilippo (2001) on Serpulidae, Sigvaldadóttir (2002) on Spionidae, Chambers and Woodham (2003) on Cirratulidae, Parapar (2003; 2006) on Oweniidae, Parapar et al. (2011c) on Opheliidae, Parapar et al. (2011b) on the Ampharetidae genus Amphicteis and Parapar et al. (2011a) on the genus Terebellides.

\section{Materials and methods}

This study is based on material collected in the framework of the BIOICE project. A total of 1371 specimens of the genus Ampharete were collected from 224 bottom samples (Fig. 1a) along the continental shelf and slope of Iceland. Several bottom samplers (modified Rothlisberg-Pearcy epibenthic sledge, detritus sledge, triangle dredge, Agassiz trawl and Shipek grab) were used during the BIOICE cruises on different research vessels (Bjarni Samundsson, Håkon Mosby and Magnus Heinason). Sampling coordinates and abiotic features of the BIOICE samples are available in the home page of the Icelandic Institute of Natural History (http://www.utgafa.ni.is/greinar/ BIOICE_station_list_91-04_Paper_A2.pdf) and also from the authors $(\mathrm{GVH})$ upon request. 

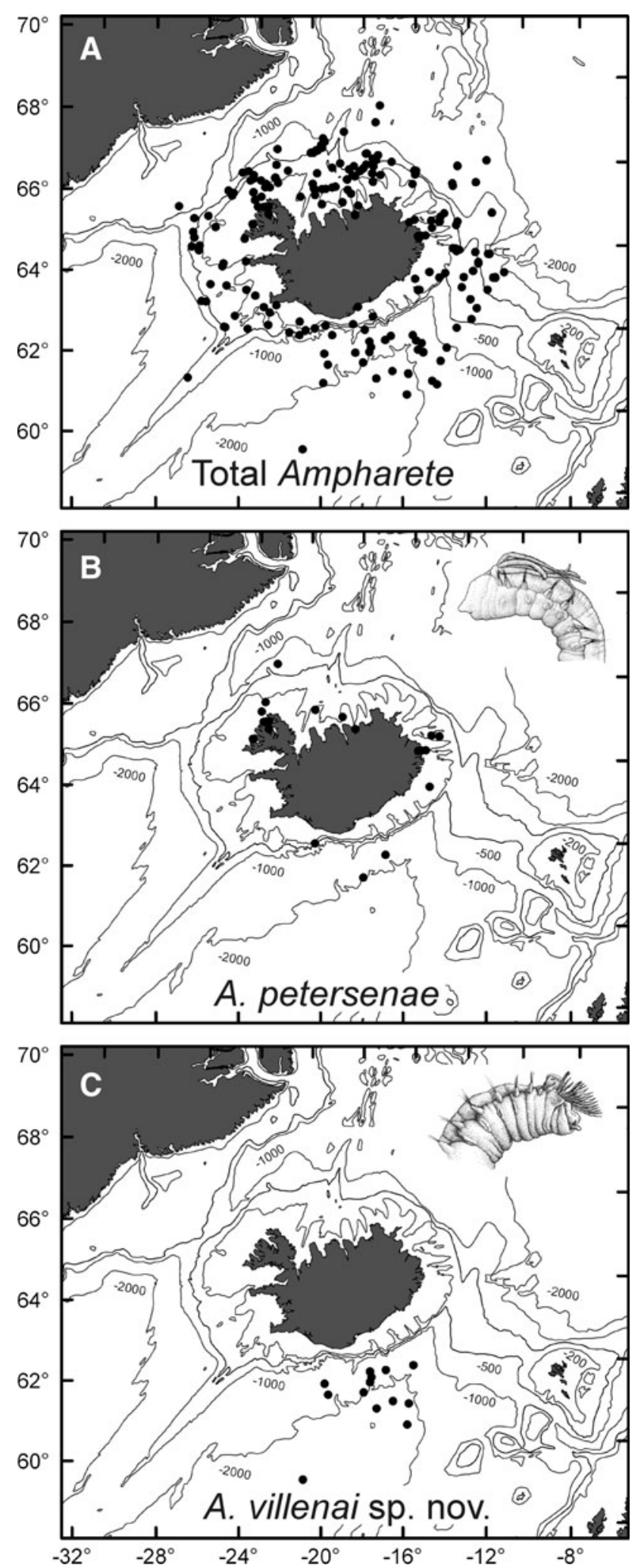

Fig. 1 Maps of Iceland showing BIOICE sampling stations with specimens of a all Ampharete species, b Ampharete petersenae, c Ampharete villenai sp. nov
Specimens were fixed in $10 \%$ formalin buffered with borax and preserved in $70 \%$ ethanol. Animals were picked from samples by the staff of the Sandgerdi Marine Centre (SMC) and then identified to species level by the authors. Most of the material examined, including the type series of the new species, was deposited in the collections of the Icelandic Museum of Natural History (IMNH, Reykjavik); some paratypes and a few specimens of other species were deposited in the Museo Nacional de Ciencias Naturales (MNCN, Madrid). Specimens used for examination with SEM were prepared by critical point drying, covered with gold in a BAL-TEC SCD 004 evaporator and examined and photographed under a JEOL JSM-6400 scanning electron microscope at the SAI (University of A Coruña-UDC, Spain).

\section{Results}

The study of the samples collected during the BIOICE project yielded eight species of the genus Ampharete sensu Jirkov (2001). Remarks on taxonomy and distribution of those species around Iceland are presented and discussed.

Family Ampharetidae Malmgren, 1866

Genus Ampharete Malmgren, 1866

Asabellides Annenkova, 1929

Sabellides Milne Edwards in Malmgren, 1866

Type species: Ampharete acutifrons (Grube, 1860) as Amphicteis

Diagnosis: Prostomium without ridges. Buccal tentacles papillose. Four pairs of branchiae. Two nephridial papillae behind branchiae. Segments III-VI without neuropodia and neurochaetae. Notochaetae of segment III usually enlarged to form paleae, but sometimes absent. Notochaetae of segment IV absent; notochaetae of segments V and VI present. Eleven or twelve uncinigerous thoracic segments. Two anterior abdominal neuropodia of thoracic type.

As already pointed by Day (1964), from the earlier reviews of the family Ampharetidae (e.g. Nilsson 1912; Hessle 1917), a confusion exists about the numbering of the segments anterior to the paleal segment. Most recent authors (Chardy and Desbruyères 1979; Holthe 1986a, b; Jirkov 2001, 2009), following the classic works of Malmgren (1866), Fauvel (1897, 1927), Caullery (1944) and Day (1964, 1967), recognize two segments and the location of the paleal chaetae in the third (III) segment. Nevertheless, Reuscher et al. (2009), following Cazaux (1982), retrieve the opinion of Annenkova (1930), Eliason (1955) and Uschakov (1965), arguing that this is based on misinterpretation of the peristomium as first segment, and therefore, 
the second (II) segment should be considered as the paleal segment. We agree with Day's (1967) opinion in considering the actual number of paleal segment as of high taxonomic value. To avoid future confusion among the descriptions of species and waiting for further contributions that may clarify this issue, here we consider the paleal segment as the third.

\section{Ampharete acutifrons (Grube, 1860)}

Amphicteis acutifrons Grube 1860: 109; Hessle 1917: 96; Annenkova 1929: 491 (in part); Wesenberg-Lund 1951: 102; Pettibone 1954: 316 (in part); Bick and Gosselck 1985: 258; Holthe 1986a: 33; HartmannSchröder 1996: 491; Kirkegaard 1996: 294; Jirkov 2001: 460.

non Ampharete grubei Malmgren 1866: 363; Fauvel 1927: 227.

Material examined: Icelandic Museum of Natural History. BIOICE sample 2044-6 specimens; 2826-1; 2827-1.

Occurrence: Eight specimens ( $0.58 \%$ of the total BIOICE Ampharete specimens) were collected in fine silt and sandy silt at shallow depths in the north-east and south coast. Depth range: $44-109 \mathrm{~m}$; temperature: $8.80^{\circ} \mathrm{C}$ (only data from 2826 and 2827 samples available).

Distribution: Ampharete acutifrons is a widely distributed Arctic-boreal species, originally described from Greenland and commonly reported from North Atlantic waters to Madeira and the Mediterranean Sea, Sea of Japan and North American Pacific (Holthe 1986a; Jirkov 2001). The southernmost finding of this species corresponds to Kirkegaard (1959) from tropical West Africa. Jirkov (2001) compared Atlantic and Pacific specimens and concluded that this taxon is likely to consist of cryptic species. Because this species was traditionally synonymized with $A$. grubei Malmgren, 1866 , it is difficult to ascertain its real geographical distribution. Previous records of this species in Icelandic waters were compiled by Wesenberg-Lund (1951).

Remarks: Ampharete acutifrons is distinguished from A. lindstroemi, the most similar species in Icelandic waters, by the presence of long (A. acutifrons) versus short (A. lindstroemi) cirri in abdominal neuropodia. Its scanty presence in BIOICE samples is probably due to the few samples taken in shallow-water substrata, which seem to be the characteristic habitat of this species (Wesenberg-Lund 1951).

Ampharete grubei Malmgren, 1866 was traditionally considered a junior synonym of $A$. acutifrons (Holthe 1986a, b; Hartmann-Schröder 1996) but it is now regarded as a valid species by Jirkov (2001). A. grubei is characterized by more numerous paleae and the absence of long cirri in abdominal neuropodia.

\section{Ampharete baltica Eliason, 1955}

Ampharete grubei baltica Eliason 1955: 26.

Ampharete baltica Holthe 1986a: 34; Hartmann-Schröder 1996: 492; Kirkegaard 1996: 296.

Material examined: Icelandic Museum of Natural History. BIOICE sample 2180-1 specimen; 2491-1.

Occurrence: Two specimens of Ampharete baltica ( $0.15 \%$ of the total BIOICE Ampharete specimens) were collected in two samples. The species is present in warm shallow waters off the north and north-west coast of Iceland. Depth range: $99-127 \mathrm{~m}$; temperature range: 5.50 $5.58^{\circ} \mathrm{C}$.

Distribution: Originally described from the Baltic Sea between Bornholm and Blekinge, Holthe (1986a) and Hartmann-Schröder (1996) reported it from the coast of Norway and Sweden, Kattegat, Øresund and western Baltic Sea and on the Arctic Jan Mayen Island. Following Holthe (1986a), the few records of this species are possibly due to confusion with juveniles or young specimens of other species. This is the first record of the species in Iceland.

Remarks: Ampharete baltica was originally described by Eliason (1955) as a subspecies of A. grubei, which, in turn, has traditionally been considered synonymous of $A$. acutifrons. Ampharete baltica was considered by Jirkov (2001) as a likely member of the Ampharete lindstroemi species complex. The study of the type material, located in the Göteborgs Naturhistoriska Museum (ref. number 11049 as A. grubei baltica), showed that the shape of the pygidium with many long and cirriform papillae (see Holthe 1986a, fig. 9) seems to be characteristic for this shallow-water taxon. However, more specimens should be analysed to assess more accurately the variability of this character, which has scarcely been used in the species discrimination in the genus Ampharete, to help determine the validity of this species.

\section{Ampharete borealis (Sars, 1856)}

Sabellides borealis Sars 1856: 22; Wesenberg-Lund 1951: 104; Holthe 1986a: 45; Holthe 1986b: 103; Hartmann-Schröder 1996: 501.

Ampharete borealis Jirkov 2001: 462.

Material examined: Icelandic Museum of Natural History. BIOICE sample 2026-1 specimen; 2046-4; 2047-2; 2049-1; 2053-29; 2054-3; 2166-1; 2265-1; 2282-1; 2340-1; 2376-1; 2415-1; 2420-1; 2423-1; 2424-13; 2530-1; 2606-2; 2665-1; 2683-1; 2830-1; 2884-2; 2937-1; 3562-2; 3565-1; 3591-2; $3642-1 ; 3668-4$.

Occurrence: 80 specimens of Ampharete borealis (5.84\% of the total BIOICE Ampharete specimens) were collected in 27 samples. The species is present across a wide range of 

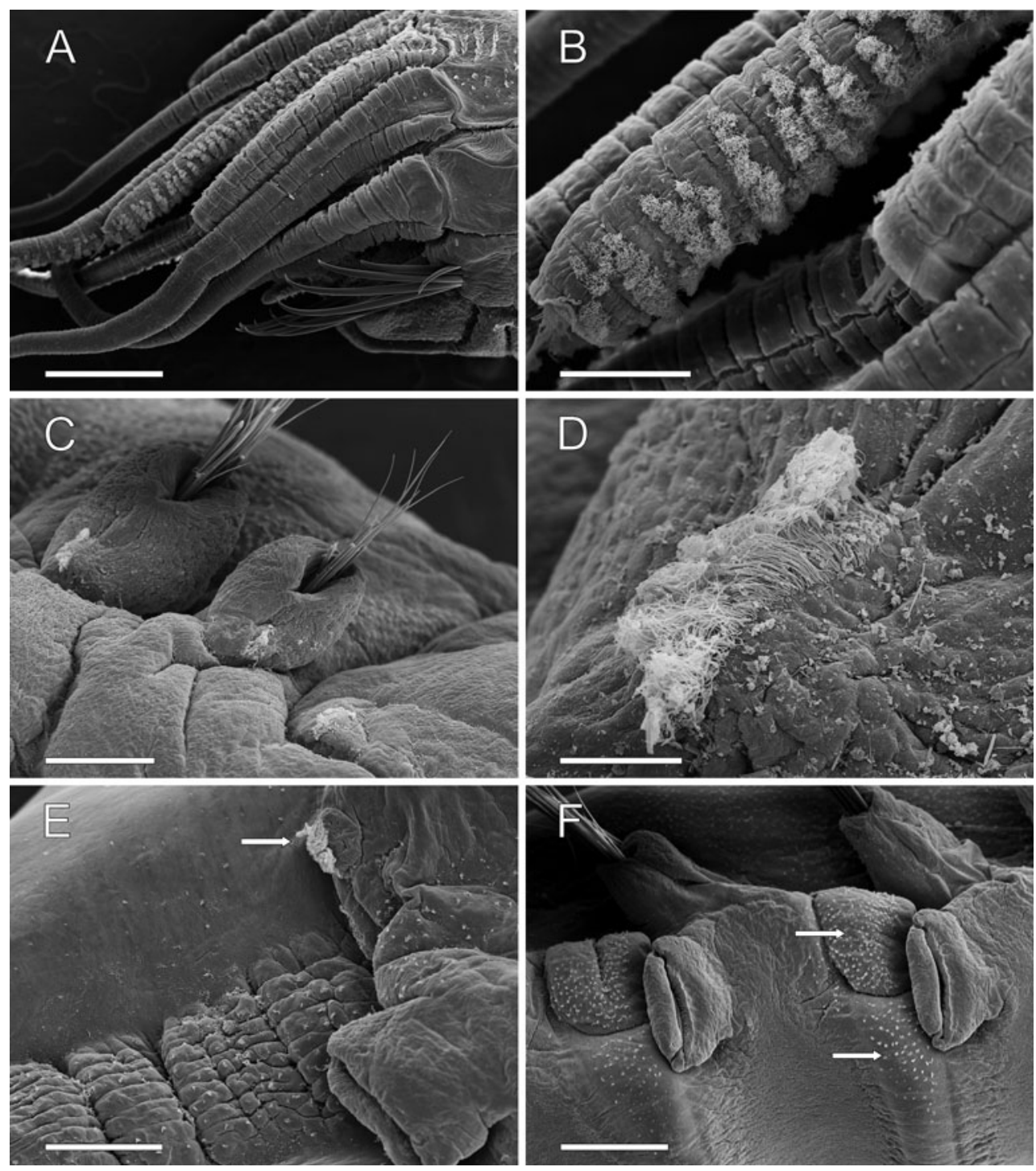

Fig. 2 Ampharete finmarchica: a anterior end, latero-dorsal view, b detail of branchial ciliature, c 1st and 2nd thoracic chaetigers, d detail of ciliature of 2 nd thoracic notopodium, e ciliature of 1 st

abdominal chaetiger (arrow), f 9th and 10th thoracic chaetigers; arrows showing position of ciliated tufts behind neuropodia. Scale bars a, c, e $300 \mu \mathrm{m} ; \mathbf{b} 100 \mu \mathrm{m} ; \mathbf{d} 40 \mu \mathrm{m} ; \mathbf{f} 500 \mu \mathrm{m}$

temperatures and depths, being found both in cold northern and warm southern coasts of Iceland. Depth range: $82-1,451 \mathrm{~m}$; temperature range: -0.77 to $7.48^{\circ} \mathrm{C}$.

Distribution: A widely distributed species in the Arctic Sea (Greenland, Canada, Iceland, Norway, Siberia and Bering Sea), down to Labrador in west Atlantic and Skagerrak in east Atlantic; Canadian Pacific (Holthe 1986a; HartmannSchröder 1996). Previous records of this species in Icelandic waters were compiled by Wesenberg-Lund (1951).

Ampharete finmarchica (Sars, 1865) (Figs. 2, 3)

Amphicteis finmarchica Sars 1865: 10.

Ampharete finmarchica Gardarsson 1973: 86; Holthe 1986a: 38; Holthe 1986b: 86; Jirkov 2001: 465;

Hartmann-Schröder 1996: 293.

Ampharete arctica Malmgren 1866: 364; Augener 1928: 777; Annenkova 1929: 490; non Imajima and Hartman 1964: 331.

non Ampharete arctica var. gagarae Uschakov 1950: 248; Uschakov 1955: 369.

Material examined: Icelandic Museum of Natural History. BIOICE sample 2010-6 specimens; 2017-1; 2025-6; 2026-2; 2031-2; 2033-2; 2036-2; 2046-8; 2047-19; 2050-1; 2051-1; 2061-7; 2074-5; 2091-6; 2094-1; 2100-9; 2110-1; 2119-1; 2129-10; 2131-1; 2137-1; 2142-4; 2145-1; 2147-2; 2150-1; 2152-1; 2154-17; 2166-8; 2167-2; 2178-1; 2266-1; 2310-2; 2313-3; 2314-10; 2318-1; 2319-6; 2320-8; 2324-2; 2328-1; 2330-2; 2332-1; 2337-3; 2340-1; 2356-4; 2357-1; 2359-4; 2360-7; 2361-2; 2362-10; 2363-1; 2366-1; 2367-2; 2371-1; 2372-4; 2374-1; 2375-2; 2376-17; 2380-3; 2382-1; 

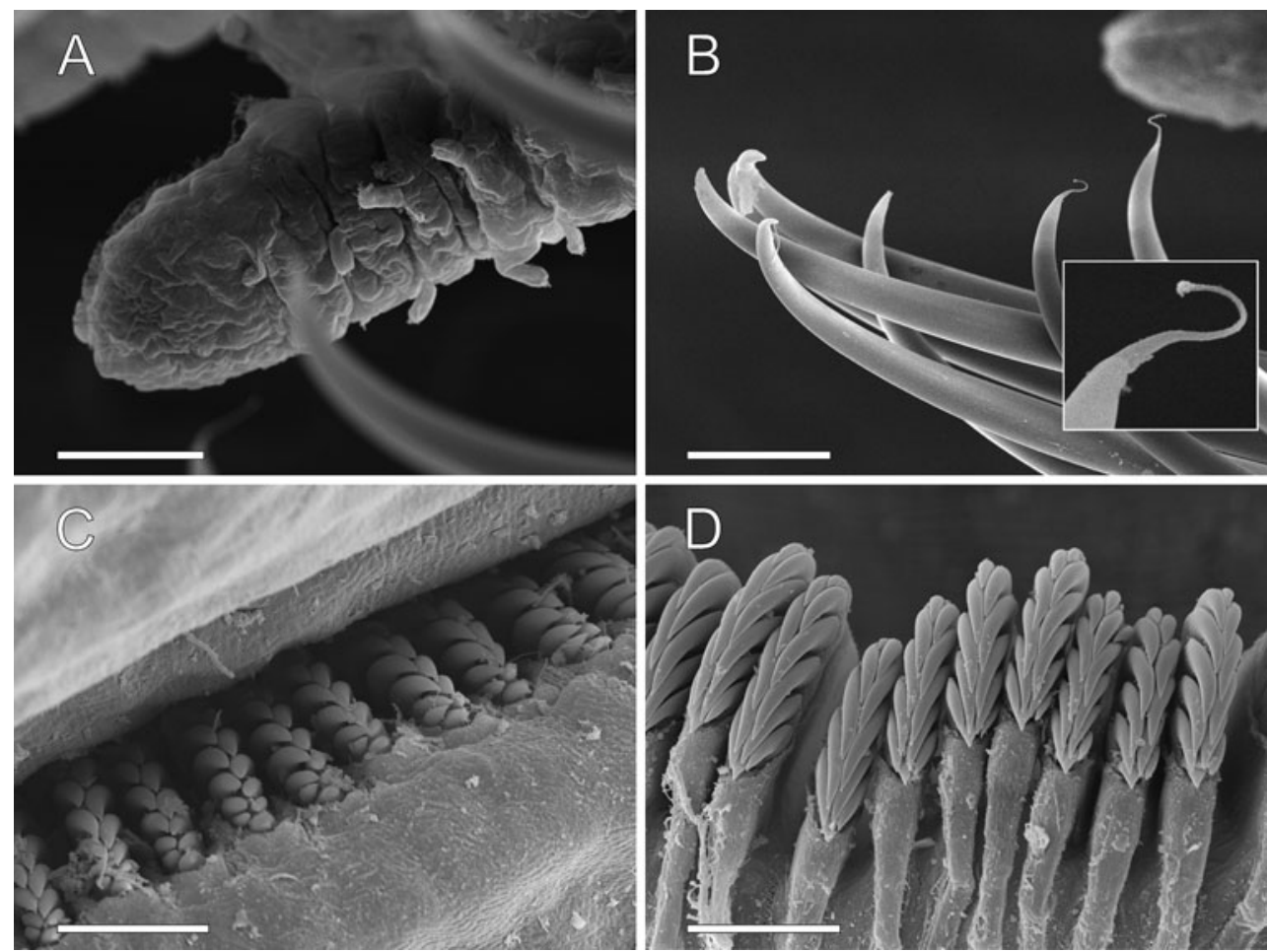

Fig. 3 Ampharete finmarchica: a Detail of papillation of buccal tentacle, $\mathbf{b}$ distal end of paleae, inserted a detail of filiform tip, $\mathbf{c}$ thoracic uncini, d abdominal uncini. Scale bars a $30 \mu \mathrm{m} ; \mathbf{b} 45 \mu \mathrm{m}$; c, d $15 \mu \mathrm{m}$

2450-8; 2475-1; 2481-9; 2512-2; 2514-1; 2522-8; 2524-24; $2526-12$; 2531-1; 2537-3; 2539-3; 2564-7; 2566-26; 25686 ; 2570-1; 2576-6; 2579-6; 2588-4; 2594-7; 2595-3; 259711 ; 2603-4; 2606-31; 2610-17; 2612-4; 2613-2; 2616-2; $2619-1 ; 2620-2 ; 2627-1 ; 2628-5 ; 2632-2 ; 2635-2 ; 2655-4$; 2662-10; 2665-30; 2666-8; 2668-5; 2672-1; 2673-12; 2681-1; 2710-5; 2740-1; 2741-8; 2754-2; 2787-2; 2792-38; 2844-1; 2867-2; 2944-2; 3033-1; 3056-3; 3069-4; 3072-2; 3092-10; 3099-8; 3114-4; 3115-9; 3124-2; 3158-24; 31591 ; 3194-2; 3195-1; 3249-1; 3260-10; 3280-74; 3282-12; $3519-6$; 3530- $;$; 3535-3; 3536-17; 3543-4; 3544-12; 36212 ; 3625-2; 3661-2; 3664-2; 3667-1; 3668-10; 3670-2.

Museo Nacional de Ciencias Naturales: BIOICE sample 2070-5 specimens; 2377-1; 2660-2; 3252-1.

Occurrence: 822 specimens of Ampharete finmarchica (59.96\% of the total BIOICE Ampharete specimens) were collected in 141 samples. The species is present from shallow waters to deep slope bottoms around Iceland. It seems to appear in fewer numbers in warm waters at the southern slope. Depth range: $44-2,708 \mathrm{~m}$; temperature range: -0.82 to $7.57^{\circ} \mathrm{C}$.

Distribution: Ampharete finmarchica is a widely distributed Arctic-boreal species commonly reported in the Atlantic and Pacific oceans (Holthe 1986a; Jirkov 2001). This species was previously reported in Icelandic waters by Wesenberg-Lund (1951) and Gardarsson (1973).
Remarks: Examination under the SEM revealed the presence of rich body ciliature. Ciliated bands were observed on the surface of branchiae (Fig. 2a, b) and ciliated tufts dorsally to the thoracic notopodia (Fig. 2c, d). The persistence of this ciliated formation in the dorsal part of abdominal segments after disappearance of notopodial ramus could lead to the erroneous observation of the presence of rudimental notopodia (Fig. 2e). Many ciliated tufts are also located on the whole dorsal body surface and in thoracic areas behind neuropodia (Fig. 2f). The papillae of the oral tentacles are short (Fig. 3a) and the paleal chaetae end abruptly in filiform tips (Fig. 3b), which are often lost. Both thoracic and abdominal uncini are similar and endowed with two vertical rows of 4-6 teeth of similar size located over the rostral tooth (Fig. 3c, d), which agrees with the drawings provided by Gardarsson (1973).

Ampharete lindstroemi Malmgren in Hessle 1917 (Fig. 4)

Ampharete lindstroemi Malmgren 1867: 214; Hessle 1917: 98; Hartmann-Schröder 1996: 494; Fournier and Pocklington 1984: 264; Holthe 1986a: 41; Holthe 1986b: 87.

Ampharete gr. lindstroemi Jirkov 2001: 467.

Material examined: Icelandic Museum of Natural History. BIOICE sample 2011-5 specimens; 2018-1; 2085-2; 2107-3; 

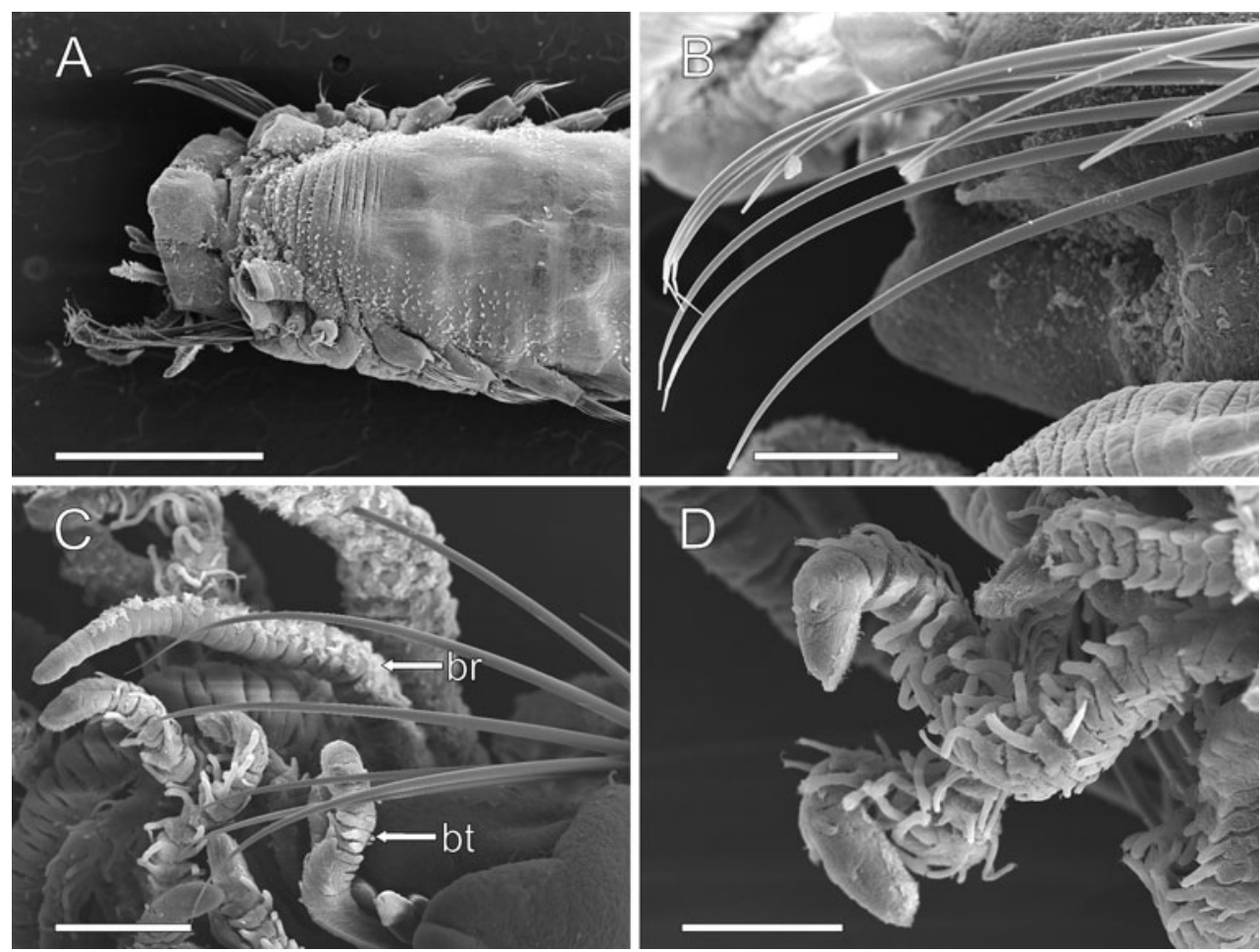

Fig. 4 Ampharete lindstroemi: a anterior end, dorsal view, $\mathbf{b}$ detail of paleae, $\mathbf{c}$ paleae and ciliation of branchiae and papillation of buccal

tentacle, $\mathbf{d}$ detail of tip of buccal tentacle. Abbreviations: $b r$ branchia, $b t$ buccal tentacle. Scale bars a $1 \mathrm{~mm}$; b, c $150 \mu \mathrm{m} ; \mathbf{d} 100 \mu \mathrm{m}$

$2132-5$; 2180-25; 2209-4; 2307-1; 2317-1; 2367-2; 2385-1; $2518-3$; 2631-2; 2779-1; 2813-1; 2868-1; 2983-4; 3061-4; $3115-1$; 3249-5; 3252-2; 3282-14; 3505-7; 3510-14; 35187 ; 3522-30; 3524-36; 3528-60; 3530-1; 3538-4; 3543-69; 3641-6; 3657-1.

Museo Nacional de Ciencias Naturales: BIOICE sample 2622-2 specimens; 3028-2.

Occurrence: Three hundred and twenty-seven specimens of Ampharete lindstroemi (23.85\% of the total BIOICE Ampharete specimens) were collected in 35 samples. This species does not show any ecological preferences when considering depth and temperature, being present from the upper shelf to the deep slope. Depth range: $99-1,940 \mathrm{~m}$; temperature range: -0.82 to $7.59^{\circ} \mathrm{C}$.

Distribution: Holthe (1986a) reports A. lindstroemi from the coast of Norway and west coast of Sweden and list records from the Gulf of St. Lawrence and Nova Scotia, the White Sea and Sea of Japan. This is the first record of the taxon in Icelandic waters.

Remarks: Jirkov (2001) suggests that, due to the ill-defined identity of this taxon, Ampharete lindstroemi would probably include a complex of several closely related species. We identified all Ampharete specimens with long, slender and evenly tapering paleae (Fig. $4 \mathrm{a}-\mathrm{c}$ ), abdominal neuropodia provided with short cirri, and pygidium with two long and a number of short cirri as A. lindstroemi. The ciliature observed on the surface of brachiae and the papillae of the oral tentacles (Fig. 4c, d) are very similar to those observed in A. finmarchica and A. petersenae.

\section{Ampharete octocirrata (Sars 1835)}

Sabella? octocirrata Sars 1835: 51.

Sabellides octocirrata Malmgren 1866: 396; Fauvel 1927: 232. Wesenberg-Lund 1951: 104; HartmannSchröder 1996: 501; Holthe 1986a: 46.

Sabellides octocirrata britannica McIntosh 1922: 75. Ampharete octocirrata Jirkov 2001: 467.

Material examined: Icelandic Museum of Natural History. BIOICE sample 2218-1 specimen; 2237-1; 2308-1; 2434-1; 2527-1; 2813-1; 2881-1; 2886-1; 2892-1; 2897-1; 3052-1; $3550-1 ; 3558-1 ; 3668-1$.

Occurrence: 14 specimens of Ampharete octocirrata (1.02\% of the total BIOICE Ampharete specimens) were collected in 14 samples. The species is restricted to warm waters at the shelf and upper slope of the southern and the north-western coast of Iceland. Depth range: 114-960 m; temperature range: $1.98-7.60^{\circ} \mathrm{C}$.

Distribution: Ampharete octocirrata seems to be widely distributed in the Atlantic Ocean including Canada, the eastern North Atlantic, the east coast of Greenland, the 


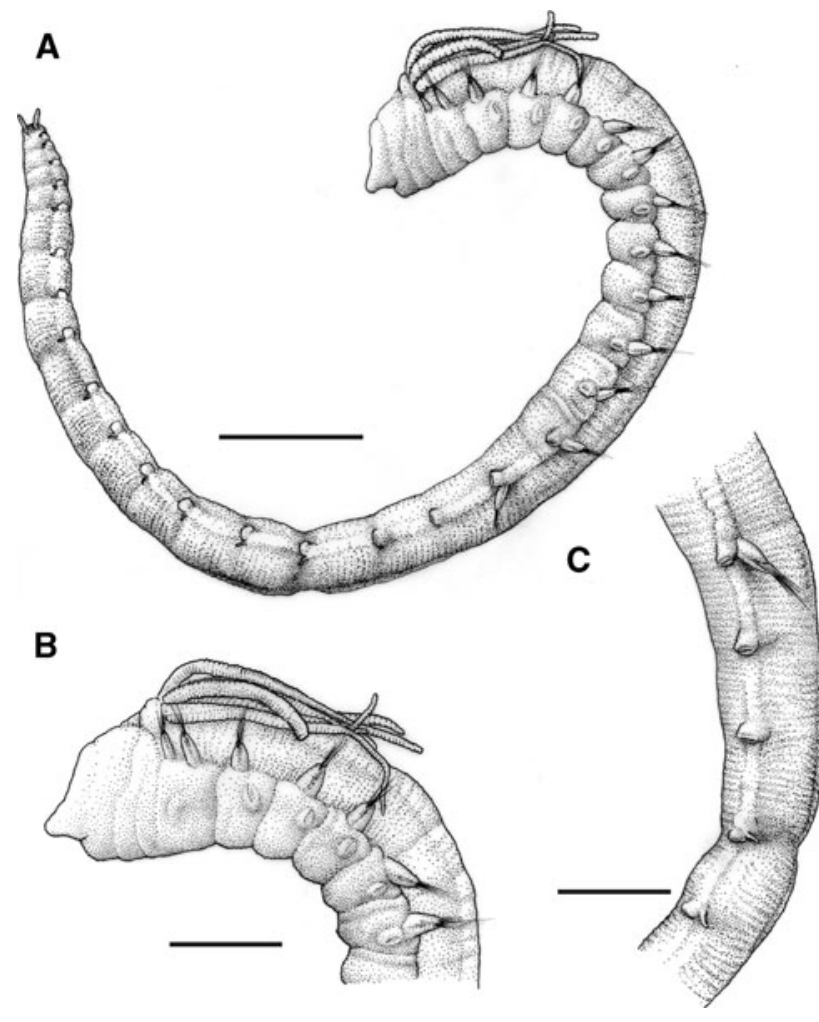

Fig. 5 Ampharete petersenae: a Specimen in lateral view, $\mathbf{b}$ anterior end in lateral view, $\mathbf{c}$ thorax-abdomen transition zone with last thoracic chaetiger (14) and first four abdominal chaetigers (15-18) in lateral view. Scale bars a $1 \mathrm{~mm} ; \mathbf{b}, \mathbf{c} 500 \mu \mathrm{m}$

Canary Islands, the Mediterranean Sea and South Africa (Holthe 1986a). It was previously reported in Icelandic waters by Saemundsson (1918) in shallow waters off northeast coast.

Ampharete petersenae Jirkov, 1997 (Figs. 1b, 5, 6, 7)

Ampharete petersenae Jirkov 1997: 1418; Jirkov 2001: 468.

Material examined: Icelandic Museum of Natural History. BIOICE sample 2000-1 specimen; 2002-1; 2003-6; 2004-1; 2047-1; 2050-1; 2062-24; 2154-1; 2178-1; 2424-1; 2480-1; 2481-1; 2491-12; 2539-1; 2540-1; 2545-3; 2546-1; 2551-1; 2562-1; 2564-1; 2582-1; 3032-1; 3283-1; 3520-1.

Occurrence: Sixty-five specimens of Ampharete petersenae (4.74\% of the total BIOICE Ampharete specimens) were collected in 23 samples. The species is distributed from shallow bottoms to the deep slope and both in cold and warm waters (Fig. 1b). Depth range: $26-1,957 \mathrm{~m}$; temperature range: -0.5 to $7.22^{\circ} \mathrm{C}$. Jirkov (1997) reports the species at $135 \mathrm{~m}$ depth and $2.67^{\circ} \mathrm{C}$.

Distribution: This is the first record of the species after the original description by Jirkov (1997) from the east coast of Iceland $\left(65^{\circ} 27^{\prime} \mathrm{N} ; 12^{\circ} 39^{\prime} \mathrm{W}\right)$. Jirkov (2001) also reports this species from a fjord on western Greenland $\left(64^{\circ} 10^{\prime} \mathrm{N}\right.$; $51^{\circ} 41^{\prime} \mathrm{W}$ ) (A. Sikorsky, pers. comm.).

Description: Body short; longest complete specimen about $11 \mathrm{~mm}$ long and $0.5 \mathrm{~mm}$ wide. Body tapering towards posterior end (Fig. 5a). No eyespots observed. Long buccal tentacles, with long papillae (Fig. 6a). Four pairs of long branchiae (Fig. 5b), with dense tufts of cilia (Fig. 6b), arranged in two groups very close to each other (Fig. 6c). No paleae. Fourteen thoracic chaetigers; first two chaetigers with slightly less developed notopodia and bristles (Figs. 5b, 6d); posterior twelve thoracic chaetigers also with neuropodia and uncini (Fig. 7a). Sixteen abdominal segments with uncinigerous neuropodia, first two abdominal uncinigerous tori of thoracic-type lacking dorsal cirri (Fig. 5c) and posterior 14 abdominal neuropodia of different shape and with dorsal cirri (Figs. 5c, 7b). Rudimentary notopodia absent. Abdominal uncini similar to thoracic ones, with 2 vertical rows of 3 teeth above rostrum (Fig. 7c). Pygidium with two lateral cirri and about 10 capitate papillae (Figs. 5a, 7d). Colour in alcohol pale yellow.

Remarks: Ampharete petersenae is characterized by possessing 12 thoracic uncinigers, 16 abdominal uncinigers (14 of them provided with short dorsal cirrus) and no paleae (Jirkov 1997).

Ampharete villenai sp. nov. (Figs. 1c, 8, 9, 10)

Type material: Icelandic Museum of Natural History: BIOICE sample 2859-2 paratypes (IMNH 26245), 3012-1 (IMNH 26246), 3067-19 (IMNH 26247), 3076-1 (IMNH 26248), 3171-1 (IMNH 26249), 3263-1 (IMNH 26250), 3282-11 (IMNH 26251), 3510 (Holotype, IMNH 26252and 1 paratype, IMNH 26253), 3519-2 (IMNH 26254), 3524-1 (IMNH 26255), 3524-3 (SEM stub, IMNH 26256), 3528-2 (IMNH 26257).

Museo Nacional de Ciencias Naturales: BIOICE sample 3522-4 paratypes (MNCN 16.01/6104).

Additional material: Moscow State University: BIOICE sample 3074-3 specimens and 3510-1 (IJ personal collection).

Type locality: South Iceland slope (BIOICE station 518; RP sledge; $62^{\circ} 14^{\prime} 41^{\prime \prime} \mathrm{N} ; 19^{\circ} 28^{\prime} 62^{\prime \prime} \mathrm{W} ; 03 / 09 / 2002 ; 1,605 \mathrm{~m}$ depth).

Occurrence: Fifty-three specimens of Ampharete villenai sp. nov. (3.87\% of the total BIOICE Ampharete specimens) were collected in 11 samples. The new species is restricted to deep slope bottoms off the south-eastern coast (Fig. 1c). Depth range: 1,605-2,270 m; temperature range: 2.34 $3.30^{\circ} \mathrm{C}$.

Description: Body short; longest complete specimen (holotype) $12 \mathrm{~mm}$ long and $1.0 \mathrm{~mm}$ wide (Fig. 8a). Thorax thicker than abdomen, of about the same length; abdomen 

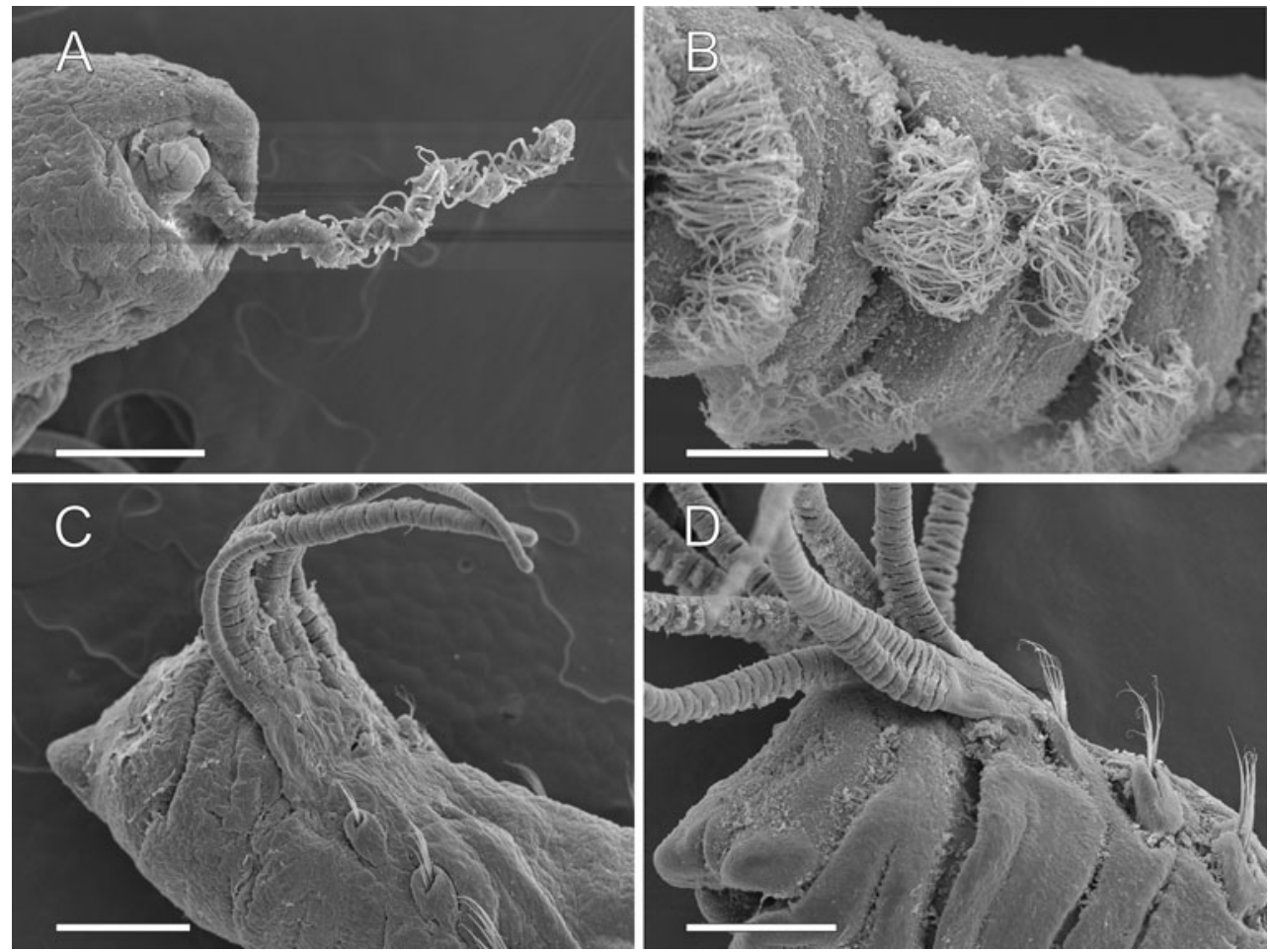

Fig. 6 Ampharete petersenae: a Detail of buccal tentacle, $\mathbf{b}$ detail of branchial ciliature, $\mathbf{c}$ anterior end in latero-dorsal view, $\mathbf{d}$ anterior end in latero-ventral view. Scale bars a, d $200 \mu \mathrm{m} ; \mathbf{b} 15 \mu \mathrm{m} ; \mathbf{c} 250 \mu \mathrm{m}$
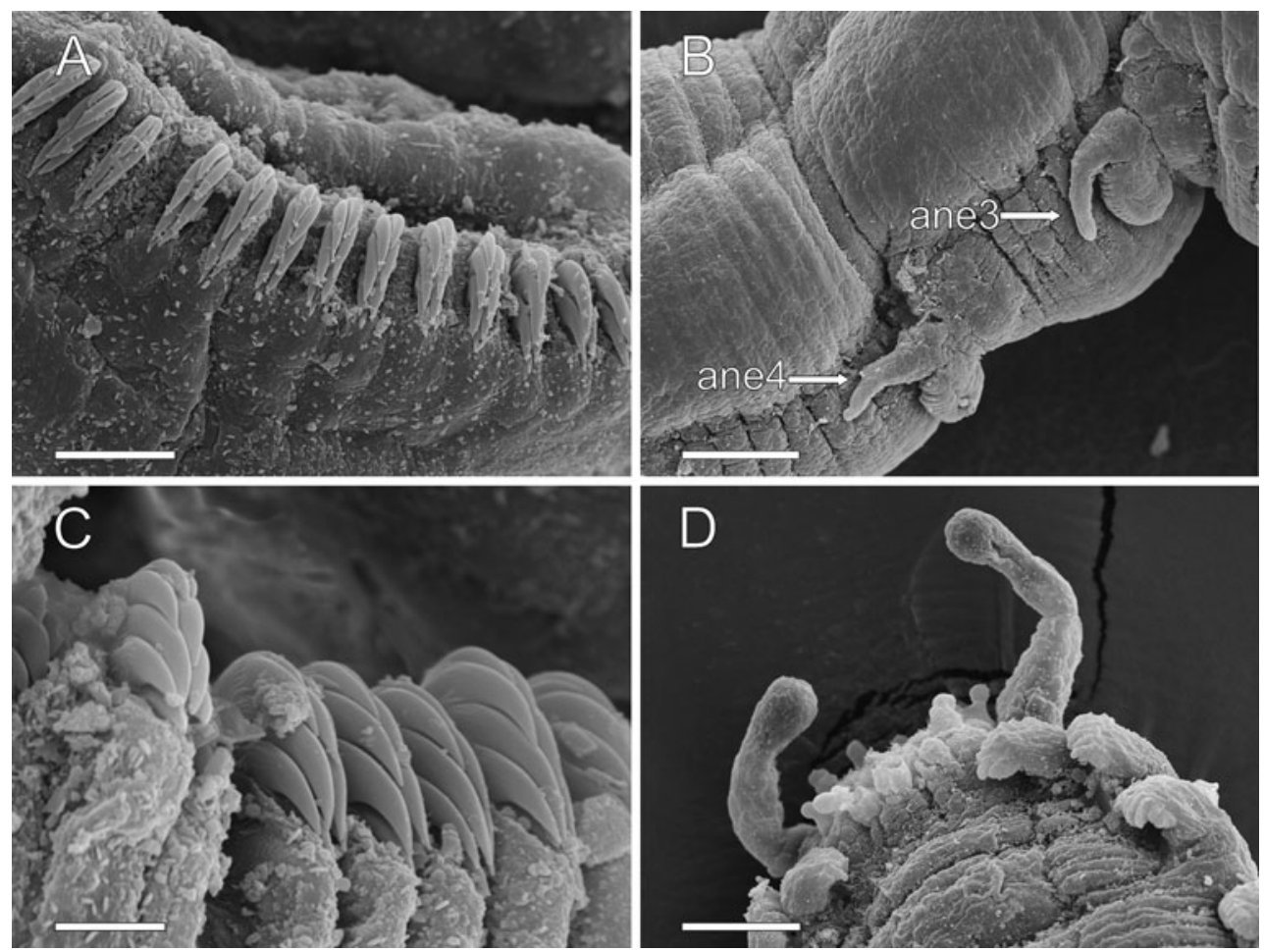

Fig. 7 Ampharete petersenae: a Detail of thoracic neuropod with uncini, $\mathbf{b}$ third and fourth abdominal chaetigers in latero-dorsal view, $\mathbf{c}$ detail of abdominal uncini, $\mathbf{d}$ pygidium in dorsal view. Abbrevia-

tions: ane abdominal neuropod. Scale bars a $15 \mu \mathrm{m} ; \mathbf{b} 100 \mu \mathrm{m}$; c $5 \mu \mathrm{m} ; \mathbf{d} 50 \mu \mathrm{m}$ 

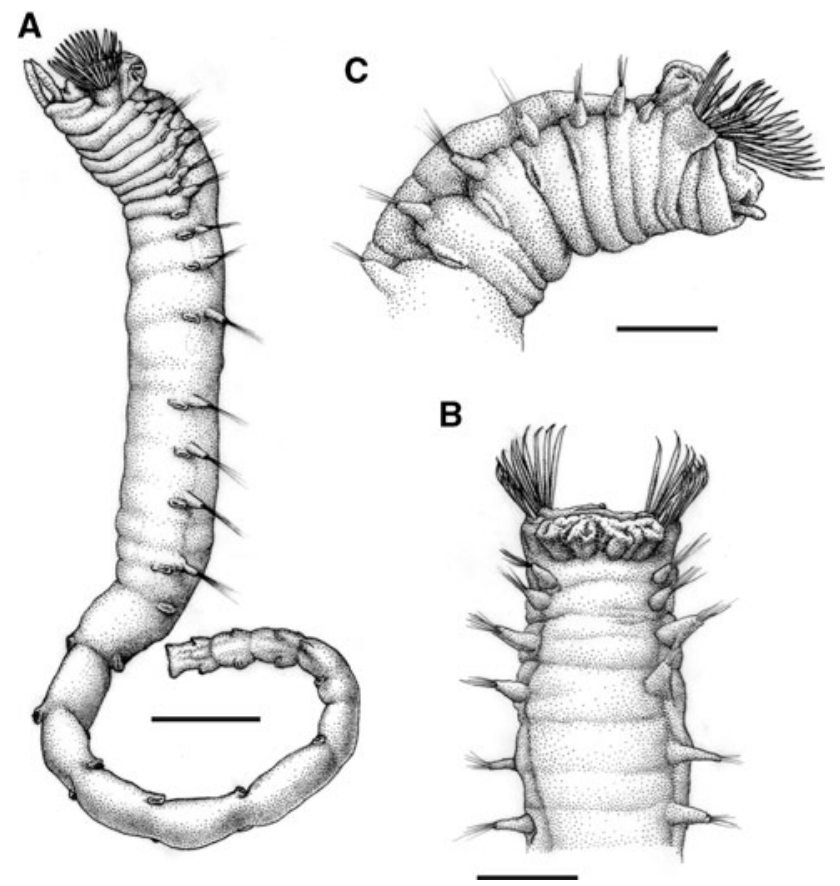

Fig. 8 Ampharete villenai sp. nov.: a Specimen in latero-ventral view (holotype, IMNH 26252), b anterior end in dorsal view (paratype, IMNH 26256), c anterior end in latero-ventral view (paratype, IMNH 26256). Scale bars a $1 \mathrm{~mm}$; b, c $600 \mu \mathrm{m}$ of nearly constant width throughout. No eyespots observed. Buccal tentacles with papillae (Fig. 9a, b). Four pairs of long branchiae arranged in two groups very close to each other (Fig. 8b); first three branchiae of each group in a transverse anterior row and the fourth one in a posterior position (Fig. 9c). Between 13 and 19 short, thick and flat paleae on each side (Figs. 8, 9a, c, d, 10a) (18 in holotype) gradually but quickly tapering to long filiform tips (Figs. 9d, 10a). Fourteen thoracic chaetigers with well-developed notopodia; the posterior twelve also with neuropodia and uncini (Fig. 10b). First two thoracic chaetigers with less developed notopodia (Fig. 9a, c). Notochaetae forming two rows; slightly flattened with a narrow brim, covered with scales and tapering into slender tips (Fig. 10c, d). Thoracic uncini with two vertical rows of 4-6 teeth each above rostrum (Fig. 10e). Twelve abdominal segments, with decreasing length towards the end; first two abdominal segments with neuropodia of thoracic type (Fig. 10b). Abdominal uncini with three horizontal rows of 6-8 teeth each above rostrum (Fig. 10f). Pygidium with a pair of short lateral lobes.

Colour in alcohol pale yellow. No tubes observed. In holotype, oocytes visible in body cavity.

The compression of the holotype's anterior abdomen was idealized to illustrate the shape of the neuropodia.
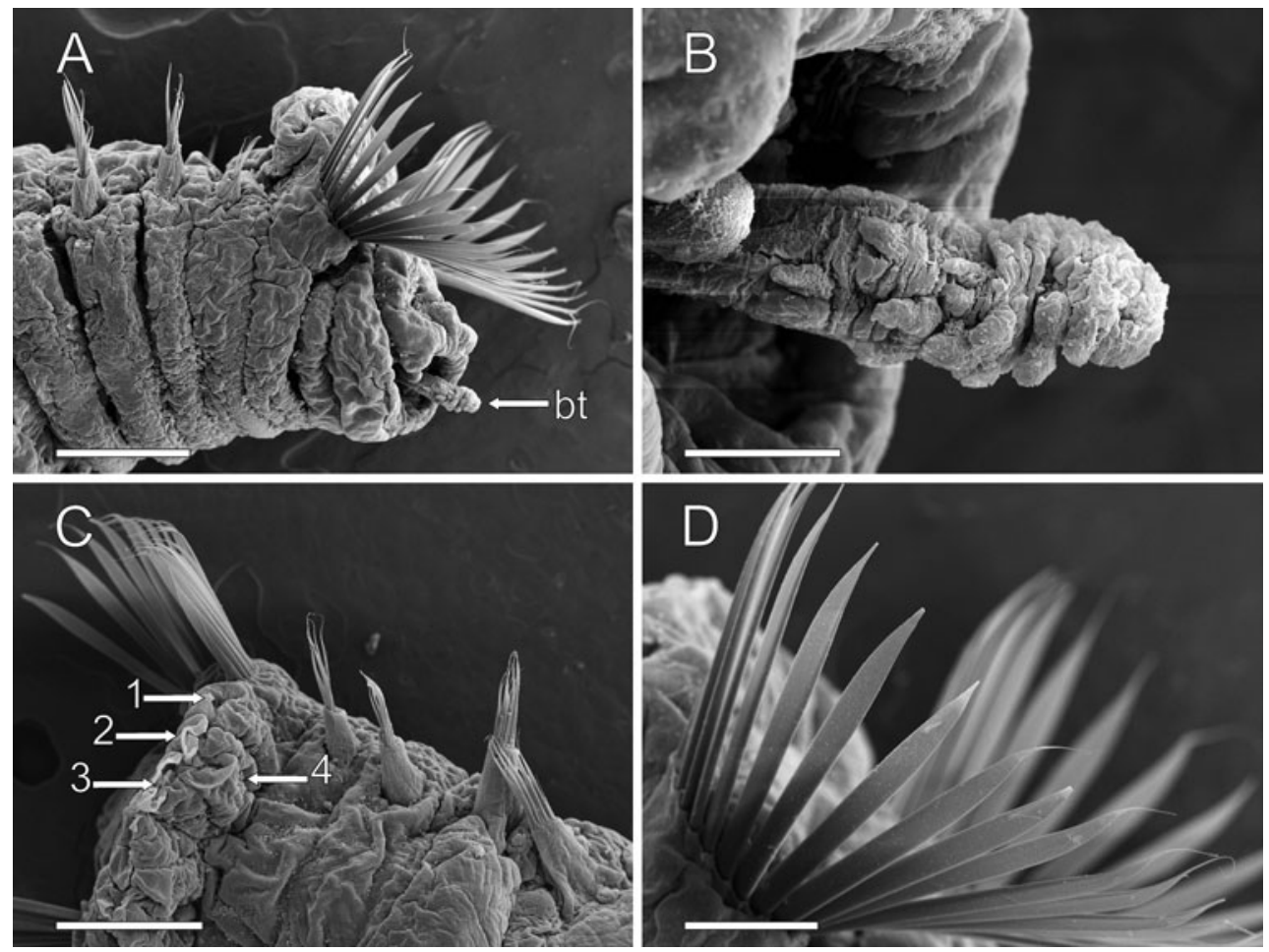

Fig. 9 Ampharete villenai sp. nov.: a Anterior end in latero-ventral view, $\mathbf{b}$ detail of buccal tentacle, $\mathbf{c}$ anterior end in dorsal view, positions of right branchiae scars numbered, $\mathbf{d}$ paleae (paratype, IMNH

26256). Abbreviations: bt buccal tentacle. Scale bars a, c $250 \mu \mathrm{m}$; b $45 \mu \mathrm{m} ; \mathbf{d} 100 \mu \mathrm{m}$ 

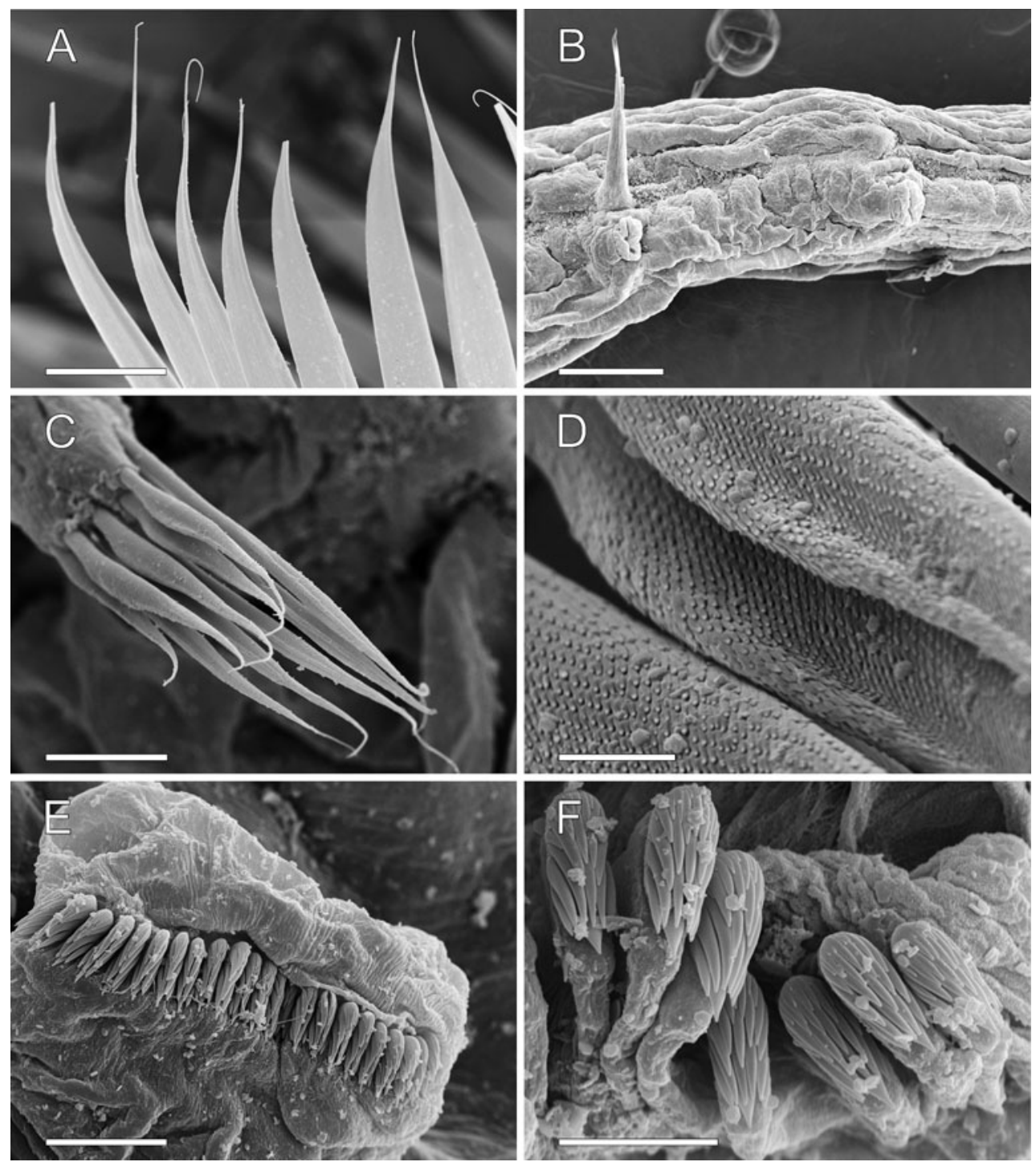

Fig. 10 Ampharete villenai sp. nov.: a Distal end of paleae, b last thoracic and first abdominal chaetiger, lateral view, $\mathbf{c}$ thoracic notochaetae from chaetiger $4, \mathbf{d}$ scale covering of thoracic notochaetae, $\mathbf{e}$ thoracic

neuropod 12 with uncini, $\mathbf{f}$ abdominal uncini (paratype, IMNH 26256). Scale bars a $50 \mu \mathrm{m}$; b $200 \mu \mathrm{m}$; $35 \mu \mathrm{m}$; d $5 \mu \mathrm{m}$; e $20 \mu \mathrm{m}$; f $10 \mu \mathrm{m}$

Etymology: The new species is named in honour of the late Dr. Miguel Villena Sánchez-Valero, curator of the Museo Nacional de Ciencias Naturales (Madrid) (SánchezAlmazán 2008).

Remarks: Ampharete villenai sp. nov. is distinguished by the number of abdominal segments (12; see keys below) from A. finmarchica (13), A.octocirrata (15-18), A. petersenae (16), A. goesi (16-18) and A. vega (26). Species that have the same number of abdominal segments include A. borealis, A. falcata, A. lindstroemi, A. baltica and A. acutifrons. However, A. borealis has very short paleae and 11 thoracic uncinigers; A. falcata has very short paleae and enlarged rudimental notopodia on the first two abdominal uncinigers, A. lindstroemi and A. baltica have both slender gradually tapered paleae, and $A$. acutifrons has long dorsal cirri in abdominal neuropodia. Also, A. villenai sp. nov. can be distinguished from the aforementioned species by the unique shape of the paleae. The paleae are arranged in a crown-like structure, resembling a leaf rake, which is unique in genus Ampharete.

\section{Key to Arctic and Boreo-Atlantic species of the genus Ampharete}

We propose two complementary keys for the North Atlantic species of the genus Ampharete sensu Jirkov (2001) providing an attempt to synthesize our knowledge about the diversity of the genus in European Arctic and Boreo-Atlantic waters. 
Key 1

This key corresponds to the traditional way of constructing a key for the group (e.g. Day 1967; Holthe 1986a; Hartmann-Schröder 1996), giving special relevance to meristic characters (e.g. number of uncinigers in thorax and abdomen, number of papillae in pygidium) and length of paleae.

1. 11 thoracic uncinigers (TU). Small paleae present 2

12 TU. Paleae present or absent

3

2. 12 abdominal uncinigers (AU)

A. borealis

15-18 AU

A. octocirrata

3. Paleae present

4

Paleae absent

A. petersenae

4. $12 \mathrm{AU}$

$13 \mathrm{AU}$

16-18 AU

24-28 AU

5. Paleae shorter than distance between the two groups of branchiae

Paleae longer than distance between the two groups of branchiae

6. Paleae stout and gradually but quickly tapering terminally

Paleae slender and evenly tapered

7. Abdominal neuropodia with long dorsal cirrus Abdominal neuropodia with short dorsal cirrus

8. Pygidium with two long cirri and a number of small papillae

Pygidium with two long cirri and a number of long papillae

Ampharete goesi, not found among the BIOICE samples, is a Arctic-boreal species (Holthe 1986b; HartmannSchröder 1996) reported in Icelandic waters by Saemudsson (1918) (as A. goësi) in shallow waters (24-28 m) of Dýrafjördur and Sigufjördur at the northern coast. Holthe (1986a) states that the type material of this species is probably lost but well-preserved syntypes from Svalbard Islands were studied by the senior author in the SMNH (cat. n. 6559-6572).

The type material of two species not found among BIOICE samples and not reported in Icelandic waters was revised: A. falcata Eliason, 1955 and A. vega (Wirén, 1883). The examination of the type material of Ampharete falcata (Göteborgs Naturhistoriska Museum, ref. number 933 (holotype) and 11053-55) showed that this species is well characterized by the wide separation between the two groups of branchiae, the very short paleae and the presence of rudimentary notopodia in the three anteriormost abdominal segments. The type material of $A$. vega was also examined (Swedish Museum of Natural History ref. number NRM 2427 (Holotype) and 2416); this Arctic species (Pettibone 1954; Holthe 1986a; Averincev 1990; Jirkov 2001) is characterized by the high number of abdominal segments (24-28) and particularly by the conspicuous rudimentary notopodia of the first two abdominal uncinigerous segments.

\section{Key 2}

The following alternative key, modified from Jirkov (2001), gives less emphasis to abdominal characters, which often cannot be tested from broken or damaged specimens, giving, however, much more relevance as distinctive characters to features of the anterior region of the body. Among these features, we consider the shape of paleae, number of thoracic uncinigers, shape of the rudimental notopodia of first two anterior abdominal uncinigers and branchial arrangement.

1. Paleae present, stout and abruptly tapered to very short filiform tips (usually missing)

Paleae present, stout and gradually but quickly A villenai sp. nov. tapering terminally to comparatively long filiform tips (rarely missing)

Paleae absent or, if present, slender and evenly 3 tapering to long filiform tip

2. 13 abdominal uncinigers (AU)

A. finmarchica

$16-18 \mathrm{AU}$

3. Rudimental notopodia of first two abdominal uncinigers enlarged

All rudimental notopodia of similar size

A. goesi

4

. Gap between branchial groups as wide as width of group. $12 \mathrm{AU}$

Gap between branchial groups narrow or absent. 24-28 AU

5. Paleae at least twice longer or wider than the most developed notochaetae

Paleae inconspicuous or absent

6. Abdominal neuropodia with long cirrus Neuropodial abdominal cirrus (if present) short

7. Pygidium with two long cirri and a number of short papillae

Pygidium with two long cirri and a number A. baltica of long papillae

8. Paleae inconspicuous; 11 thoracic uncinigers (TU) 9

Paleae absent; 12 TU

A. petersenae

9. Three branchiae in each group arranged in a strait A. borealis transversal line and one behind

All four branchiae arranged in a strait transversal line

A. octocirrata

Acknowledgments This work was partially supported by several grants from the European Union's TMR programme and the UDC to the senior author to visit the SMC. JP also gratefully acknowledges Synthesys support made available by the European Community-Research Infrastructure Action under the FP6 Structuring the European Research Area (Projects DK-TAF-3118 and SE-TAF-4599) to visit the Zoological Museum, University of Copenhagen, and the Swedish Museum of Natural History (Stockholm) and also to Danny Eibye-Jacobsen and Majken Them Tøttrup (ZMUC) and Elin Sigvaldadottir and Karin Sindemark (SMNH) for their help during his stay in both institutions. Special thanks to Solrun Bragadottir and the rest of the women of the 
SMC involved in sorting the specimens from the BIOICE samples. The authors wish to thank Ada Castro and Catalina Sueiro (SAIN, UDC) who assisted with the preparation of specimens and use of the SEM. David Romero (UDC) made the line drawings, Julia García-Carracedo revised the English version of the manuscript and Noela Sánchez (UDC) prepared the maps. Two anonymous referees provided useful comments that greatly contributed to improve this paper.

\section{References}

Annenkova N (1929) Beiträge zur Kenntis der Polychaeten-Fauna der USSR. 1. Fam. Pectinariidae Quatrefages (Amphictenidae Malmgren) und Ampharetidae Malmgren. Annu Mus Zool Acad Sci USSR 30:477-502

Annenkova N (1930) Zur polychaetenfauna von Franz-Joseph-Land. Zool Anz 95:269-272

Augener H (1928) Die Polychaeten von Spitzbergen. Fauna Arct $5(3): 647-834$

Averincev VG (1990) The polychaetous fauna of the Laptev Sea. Issledovaniya fauny morei (Investigations of sea fauna) 37(45):147-186 [In Russian with English summary]

Bick A, Gosselck F (1985) Arbeitsschlüssel zur Bestimmung der Polychaeten der Ostsee. Mitt Zool Mus Berl 61:171-272

Caullery M (1944) Polychètes sédentaires de l'expédition du Siboga. Ariciidae, Spionidae, Chaetopteridae, Chlorhaemidae, Opheliidae, Oweniidae, Sabellariidae, Sternaspidae, Amphictenidae, Terebellidae. Siboga Expeditie 24 bis:1-204

Cazaux C (1982) Développement larvaire de l'Ampharetidae lagunaire Alkmaria romijni Horst, 1919. Cah Biol Mar 23:143-158

Chambers SJ, Woodham A (2003) A new species of Chaetozone (Polychaeta: Cirratulidae) from deep water in the northeast Atlantic, with comments on the diversity of the genus in cold northern waters. Hydrobiologia 496:41-48

Chardy P, Desbruyères D (1979) La classification multicritère. Application a la révision de la sous-Familie des Ampharetinae (Annélides Polychètes). Ann Biol 18(11-12):521-537

Day JH (1964) A review of the family Ampharetidae (Polychaeta). Ann S Afr Mus 48:97-120

Day JH (1967) A monograph on the Polychaeta of Southern Africa. Part 2. Sedentaria. Trustees of the British Museum (Natural History), London

Eliason A (1955) Neue oder wenig bekannte schwedische Ampharetiden (Polychaeta). Göteborgs K Vetensk-o vitterh Samh Handl (B) 6(16):1-17

Fauvel P (1897) Recherches sur les ampharétiens, annélides polychètes sédentaires. Morphologie, anatomie, histologie, physiologie. Bull sci Fr Belg 30:277-488

Fauvel P (1927) Polychètes sédentaires. Addenda aux Errantes, Archiannélides, Myzostomaires. Faune de France 16:1-494

Fournier JA, Pocklington P (1984) The sublittoral polychaete fauna of the Bras d'Or lakes, Nova Scotia, Canada. In: Hutchings P (ed) Proceedings of the 1st International Polychaete Conference, Sydney Australia. Linn Soc, New South Wales, pp 254-278

Gardarsson A (1973) Some polychaetes new to the Icelandic fauna. Sérprentun úr Náttúrfrædingurinn 43:77-91 [In Icelandic with English summary]

Grube AE (1860) Beschreibung neuer order wenig bekannter Anneliden. Arch Naturgesch Berlin 26:71-118

Hartmann-Schröder G (1996) Annelida, Borstenwürmer, Polychaeta. Die Tierwelt Deutschlands, vol 58, 2nd edn. Gustav Fischer, Jena

Hessle C (1917) Zur Kenntnis der terebellomorphen Polychaeten. Zool Bidr Uppsala 5:39-258

Holthe T (1986a) Polychaeta Terebellomorpha. Mar Invertebr Scand $7: 1-194$
Holthe T (1986b) Evolution, systematics, and distribution of the Polychaeta Terebellomorpha, with a catalogue of the taxa and a bibliography. Gunneria 55:1-236

Hutchings P, Peart R (2000) A revision of the Australian Trichobranchidae (Polychaeta). Inv Tax 14:225-272

Imajima M, Hartman O (1964) The polychaetous annelids of Japan. Part II. Allan Hancock Foundation Publications, Occ. Paper 26. University of Southern California Press, Los Angeles

Jirkov IA (1994) Two new species of Ampharete (Polychaeta: Ampharetidae) from the North-Western Pacific with discussion of paleae as taxonomic character of Ampharetinae. Zool Zh 73:28-32 [English translation from Russian]

Jirkov IA (1997) Ampharete petersenae sp. n. (Ampharetidae, Polychaeta) from the Northern Atlantic. Zool Zh 76(12):1418-1420 [in Russian with English summary]

Jirkov IA (2001) Polychaeta of the Arctic Ocean. Yanus-K., Moscow [in Russian]

Jirkov IA (2009) Revision of Ampharetidae (Polychaeta) with modified thoracic notopodia. Inv Zool 5:111-132

Jouin-Toulmond C, Hourdez S (2006) Morphology, ultrastructure and functional anatomy of the branchial organ of Terebellides stroemii (Polychaeta: Trichobranchidae) and remarks on the systematic position of the genus Terebellides. Cah Biol Mar 47:287-299

Kirkegaard JB (1959) The Polychaeta of West Africa. Part I. Sedentary species. Atlantide Report. Scientific Results of the Danish Expedition to the coasts of tropical West Africa, 1945-1946 5:7-117

Kirkegaard JB (1996) Danmarks Fauna, 86. Havbørsteorme II. Dansk Naturhistorisk Forening, København, pp 1-451

Kirkegaard JB (2001) Polychaetes of the families Glyceridae, Goniadidae, and Nereididae from the North Atlantic around Iceland. Sarsia 86:13-20

Malmgren AJ (1866) Nordiska Hafs-Annulater. Öfvers K Vetensk Akad Stockh Förh 22:355-410

Malmgren AJ (1867) Annulata polychaeta. Spetsbergiae, Grönlandiae, Islandiae et Scandinaviae hactenus cognita. Öfv Kongl VetenskAkad Förh 4:127-235

McIntosh WC (1922) A monograph of the British marine annelids, Polychaeta. Hermellidae to Sabellidae. Ray Soc Lon 4(1):1-250

Nilsson D (1912) Beiträge zur kenntnis der nervensystems der polychaeten. Zool Bidr Uppsala 1:85-161

Parapar J (2003) Oweniidae (Annelida, Polychaeta) from Icelandic waters, collected by the BIOICE project, with a description of Myrioglobula islandica n. sp. Sarsia 88:274-290

Parapar J (2006) The genera Myriochele and Myrioglobula (Polychaeta, Oweniidae) in Icelandic waters with the revision of type material of Myriochele heeri Malmgren, 1867, and the description of a new species. J Nat Hist 40:523-547

Parapar J, Moreira J (2008a) Redescription of Terebellides kerguelensis (Polychaeta: Trichobranchidae) from Antarctic and subantarctic waters. Helgol Mar Res 62:143-152

Parapar J, Moreira J (2008b) Revision of three species of Terebellides (Polychaeta: Trichobranchidae) described by C. Hessle in 1917 from the Southern Ocean. J Nat Hist 42(17-18):1261-1275

Parapar J, Moreira J, Helgason GV (2011a) Taxonomy and distribution of Terebellides (Polychaeta, Trichobranchidae) in Icelandic waters, with the description of a new species. Zootaxa 2983:1-20

Parapar J, Helgason GV, Jirkov I, Moreira J (2011b) Taxonomy and distribution of the genus Amphicteis (Polychaeta: Ampharetidae) collected by the BIOICE project in Icelandic waters. J Nat Hist 45(23-24): 1477-1499

Parapar J, Moreira J, Helgason GV (2011c) Distribution and diversity of the Opheliidae (Annelida, Polychaeta) on the continental shelf and slope of Iceland, with a review of the genus Ophelina in northeast Atlantic waters and description of two new species. Org Div Evol 11:83-105 
Petersen M (2000) A new genus of Fauveliopsidae (Annelida: Polychaeta), with a review of its species and redescription of some described taxa. Bull Mar Sci 67:491-515

Pettibone MH (1954) Marine polychaete worms from Point Barrow, Alaska, with additional records from the North Atlantic and North Pacific. Proc US Nat Mus 103:203-356

Reuscher M, Fiege D, Wehe T (2009) Four new species of Ampharetidae (Annelida: Polychaeta) from Pacific hot vents and cold seeps, with a key and synoptic table of characters for all genera. Zootaxa 2191:1-40

Saemundsson B (1918) Bidrag til kundskaben om Islands polychaete børsteorme (Annulata polychæta Islandiæ). Vid Medd dansk naturh Foren Kbh 69:165-241

Salazar-Vallejo SI (1996) Sabellides manriquei new species from the eastern Pacific, and redescription of Sabellides oculata Webster from the Northwestern Atlantic (Polychaeta: Ampharetidae). Bull Mar Sci 59:142-149

Sánchez-Almazán J (2008) Necrológica. Miguel Villena SánchezValero y la memoria del Museo Nacional de Ciencias Naturales. Graellsia 64:139-141
Sanfilippo R (2001) Bathyvermilia islandica (Polychaeta, Serpulidae): a new deep-water species from south of Iceland. Sarsia 86:177182

Sars M (1835) Beskrivelser og Iagttagelser over nogle mærkelige eller nye i Havet ved den Bergenske Kyst Levende Dyr af Polypernes, Acalephernes, Radiaternes, Annelidernes og Molluskernes Classer, med en kort Oversigt over de hidtil af Forfatteren sammesteds fundne Arter og deres Forekommen, Bergen

Sars M (1856) Nye annelider. Fauna littoralis Norvergiae 2:1-24

Sigvaldadóttir E (2002) Polychaetes of the genera Prionospio and Aurospio (Spionidae, Polychaeta) from Icelandic waters. Sarsia 87:207-215

Uschakov PV (1950) Mnogoščetinkovye červi (Polychaeta) Okhotskogo morja. Issled Dal'nev Morei SSSR 2:140-234

Uschakov PV (1955) Mnogoščetinkovye červi (Polychaeta) dal'nevostocnyh morej SSSR. Fauna SSSR 56:1-445

Uschakov PV (1965) Polychaeta of the Far Eastern Seas of the USSR. Zool Inst Acad Sci USSR 56:1-419 [translated from Russian by the Israel Program for Scientific Translations, Jerusalem]

Wesenberg-Lund E (1951) Polychaeta. Zool Icel 2:1-182 